\title{
PENGEMBANGAN PENDIDIKAN ANTIKORUPSI BERBASIS KANTIN KEJUJURAN DI SEKOLAH DASAR
}

\author{
Imam Nawawi \\ Jurusan KSDP Fakultas Ilmu Pendidikan Universitas Negeri Malang \\ Jl. Semarang No.5 Malang \\ E-mail:imam_nawawi_fipum@yahoo.com
}

\begin{abstract}
The study aims at finding the pattern of the right development of anti-corruption education through the use of honest school canteen system (kantin kejujuran) for primary school students. The study was done in descriptive qualitative and also quantitative study. The data were obtained through giving the questionnaire to the headmasters and teachers at primary school. Both of qualitative and quantitative data from teachers and students were analysed in the descriptive analysis. The result of the study showed that honest school canteen system (kantin kejujuran ) can help primary school students to internalize discipline and honesty values. In conclusion, the development of anti-corruption education at primary schools has to be integrated into classroom activities and real-life activities at school.
\end{abstract}

Keywords: anti-corruption education, honest school canteen system.

\begin{abstract}
Abstrak: Penelitian ini bertujuan menemukan pola pengembangan pendidikan antikorupsi yang tepat melalui pemanfaatan kantin kejujuran bagi para siswa Sekolah Dasar. Penelitian ini dilakukan secara deskriptif kualitatif maupun kuantitatif. Pengambilan data menggunakan angket yang ditujukan pada kepala sekolah dan para guru kelas. Data penelitian ini dianalisis secara deskriptif, baik berupa data kuantitif maupun data kualitatif, data dari guru maupun data dari siswa. Hasil penelitian ini menunjukkan bahwa kantin kejujuran sebagai proses internalisasi nilai kejujuran dan kedisiplinan anak SD. Kesimpulannya pengembangan pendidikan antikorupsi di sekolah dasar perlu dilaksanakan secara terintegrasi dengan berbagai teme pembelajaran di kelas dan praktik kehidupan di sekolah.
\end{abstract}

Kata kunci : pendidikan antikorupsi, kantin kejujuran

Sekolah merupakan lembaga pendidikan yang ikut bertanggungjawab dalam upaya membentuk pribadi positif. Terutama di tingkat sekolah dasar (SD) perilaku-perilaku positif perlu dibentuk sejak awal sebagai pondasi dalam membangun jiwa antikorupsi pada anak-anak SD. Korupsi adalah persoalan nilai, dalam hal ini korupsi memiliki nilai yang buruk, karena didalamnya mengandung keburukan, kebejatan, ketidakjujuran, tidak bermoral dan penyimpangan dari kesucian (Kemendikbud, 2011:23). Salah satu unsur jiwaan (perilaku) antikorupsi yang perlu dikembangkan adalah kejujuran. Kejujuran merupakan sifat terpuji yang harus dimiliki setiap orang. Kejujuran seorang hamba akan mencapai derajat orang-orang yang mulia dan selamat dari segala keburukan. Sifat kejujuran perlu ditanamkan dalam diri seseorang sedini mungkin, karena kejujuran merupakan tanggungjawab moral seseorang terhadap nilai-nilai dan normanorma agama dan masyarakat. Penanaman sifat kejujuran di sekolah harus ditekankan sebab tujuan pendidikan tidak hanya berujung pada peningkatan kecerdasan intelegensi semata, namun juga harus diiringi dengan peningkatan kualitas budi pekerti. 
Penanaman kejujuran melibatkan tiga pilar utama, yakni keluarga, sekolah, dan masyarakat. Sekolah merupakan lembaga pendidikan yang ikut bertanggungjawab dalam upaya membentuk perilaku positif. Menurut Aditjondro, beberapa Negara telah melaksanakan pendidikan antikorupsi di sekolah dan telah menunjukan hasil yang signifikan.

Berdasarkan pengamatan peneliti ketika menjalankan tugas pendampingan PPL Mahasiswa di SD ditemukan masalah-masalah faktual berkaitan dengan praktik pendidikan anti korupsi. Diantaranya masalah-masalah pendidikan antikorupsi yang ditemukan adalah adanya rasa tanggungjawab dan rasa memiliki fasilitas sekolah oleh siswa relatif rendah, bahkan ada perilaku yang cenderung merusak fasilitas sekolah, masalah kejujuran dalam bertindak, terdapat siswa-siswa dari kelas yang lebih tinggi suka menipu dan membohongi adik kelasnya misalnya minta uang, minta mainan, melarang adik kelas melintas di depan kelas kakaknya.

Dalam rangka lebih memperkuat pelaksanaan pendidikan karakter telah teridentifikasi 18 nilai yang bersumber dari agama, Pancasila, budaya dan tujuan pendidikan nasional, yaitu: (1) religius, (2) jujur, (3) toleransi, (4) disiplin, (5) kerja keras, (6) kreatif, (7) mandiri, (8) demokratis, (9) rasa ingin tahu, (10) semangat kebangsaan, (11) cinta tanah air, (12) menghargai prestasi, (13) bersahabat/komunikatif, (14) cinta damai, (15) gemar membaca, (16) peduli lingkungan, (17) peduli sosial, \& (18) tanggung jawab (Puskur, 2009:9-10).

Pengembangan pendidikan karakter berbasis kantin kejujuran tersebuttentu tidak terlepas dari peran berbagai pihak dan kondisi lingkungan sekolah dalam mensosialisasikan serta menginternalisasikannya kepada siswa. Nilai adalah sesuatu yang dijunjung tinggi, yang dapat mewarnai dan menjiwai tindakan seseorang (Adisusilo, 2011). Pengembangan kantin kejujuran tersebut dapat diterapkan dalam rangka menanamkan nilai-nilai kejujuran kepada peserta didik sejak dini. Tantangannya kemudian adalah bagaimana mengembangkan karakter siswa berbasis kantin kejujuran dengan melestarikan nilai-nilai yang terkandung di dalamnya. Karakter berasal dari nilai tentanng sesuatu. Suatu nilai yang diwujudkan dalam bentuk perilau anak itulah yang disebut karakter. Jadi suatu karakter melekat dengan nilai dari perilaku tersebut. Karenanya tidak ada perilaku anak yang tidak bebas dari nilai (Kesuma, 2012). Memelihara dan memperkuat nilai-nilai kejujuran tersebut tentulah harus tercermin dalam keseluruhan proses penyelenggaraannya. Pengembangan karakter seseorang tidak dapat dilepaskan dari konteks kehidupan (Akbar, 2010), lingkungan sosial dan budaya setempat (Thalib, 2012).

Pentingnya pengembangan pendidikan antikorupsi yang berbasis kantin kejujuran di sekolah dasar didasari pemikiran bahwa pada hakikatnya manusia dilahirkan dalam keadaan suci dan baik, Seorang anak dilahirkan dengan potensi menjadi manusia yang berkarakter baik. Tugas sekolah adalah berupaya untuk menjadikan siswa-siswinya menjadi manusia yang berkarak terbaik. Kerangka dasar filosofis sementara untuk mengembangkan moralitas peserta didik dalam pendidikan antikorupsi di sekolah. Beberapa pendekatan yang perlu dipertimbangkan: (1) pembentukan kebiasaan, (2) pembelajaran, (3) pemodelan (social learning). Semua pendekatan ini cukup relevan dicermati dan diformulasikan ulang agar target transfer of learning, transfer of values, dan transfer of principles dapat berinteraksi dengan persoalan dan realitas sosial di kalangan siswa (Ghofur, 2009). Mereka diharapkan dapat menjadi manusia yang dapat hidup dengan benar dalam hubungannya dengan Tuhan, manusia lain, alam lingkungannya, dan dengan dirinya sendiri.

Berdasarkan latar belakang di atas, permasalahan utama pada penelitian ini adalah bagaimana mengidentifikasi: (a) mendeskripsikan pelaksanaan pengembangan pendidikan antikorupsi yang berbasis kantin kejujuran bagi siswa SD, (b) mendeskripsikan masalah-masalah yang berkaitan dengan pelaksanaan pengembangan pendidikan antikorupsi yang berbasis kantin kejujuran di SD, (c) mendesain panduan penerapan kantin kejujuran terhadap pendidikan antikorupsi siswa SD, dan (d) sosialisasi panduan pelaksanaan kantin kejujuran terhadap pengembangan pendidikan antikorupsi bagi siswa SD.

\section{METODE}

Rancangan penelitian yang digunakan adalah kualitatif dan kuantitatif yang fokuskan pada pendidikan antikorupsi di sekolah dasar. Penelitian ini akan memecahkan masalah penelitian yang berkaitan dengan: (a) Mendeskripsikan pelaksanaan pengembangan pendidikan antikorupsi yang berbasis kantin kejujuran bagi siswa sekolah dasar; (b) mendeskripsikan masalah-masalah yang berkaitan dengan pelaksanaan pengembangan pendidikan 
antikorupsi yang berbasis kantin kejujuran di sekolah dasar; (c) mendesain panduan penerapan kantin kejujuran terhadap pendidikan antikorupsi siswas ekolah dasar; dan (d) sosialisasi panduan pelaksanaan kantin kejujuran terhadap pengembangan pendidikan antikorupsi bagi siswa sekolah dasar.

Penelitian ini metode penelitian survey karena merupakan upaya pengumpulan informasi dari sebagian populasi yang dianggap dapat mewakili populasi tertentu. Metode ini bertitik tolak pada konsep, hipotesis, dan teori yang bersifat verifikasi terhadap teori yang sudah ada. Rancangan penelitian survey ini dipilih karena data yang akan diambil adalah informasi tentang pola pengembangan pendidikan karakter yang berbasis kantin kejujuran di sekolah dasar.

Populasi penelitian ini adalah para siswa sekolah dasar di kelas awal atau kelas rendah yang meliputi kelas 1, 2, dan 3, dan kelas tinggi yang meliputikelas 4, 5, dan 6. Sampel yang diambil pada masing-masing kelas pararel.

\section{HASIL}

Berdasarkan hasil survey, diperoleh data tentang pengembangan pendidikan antikorupsi di Sekolah Dasar yang meliputi (1) pengembangan nilai sikap tanggung jawab anak; (2) pengembangan nilai kejujuran; (3) pengembangan nilai dan norma agama; (4) pengembangan nilai sportifitas; dan (5) nilai kejujuran dalam membeli jajanan di kantin.

Selain nilai-nilai tesebut di atas, sekolah juga mengembangkan nilai dalam visi, misi, dan tujuan pendidikan sekolah. Nilai tersebut meliputi nilai keimanan dan ketaqwaan, kecerdasan dan ketrampilan, kemandirian, kejujuran, kepedulian, kedisiplinan, kreatifitas, semangat berprestasi, dan berakhlak mulia. Nilai kehidupan keseharian anak adalah keteladanan penilaian dan sikap jujur dari guru dan staf sekolah.

Kantin kejujuran yang digunakan bagi proses internalisasi nilai kejujuran, kedisiplinan, dan tanggung jawab serta nilai-nilai positif lainnya dalam kehidupan anak adalah dengan dibuatnya tata tertib pengguna kantin kejujuran di sekolah. Persentase penggunaan tata tertib siswa sebagai fasilitas bagi proses internalisasi nilai-nilai kejujuran di masingmasing kelas meliputi: kelas I 98\%, kelas II 97\%, kelas III 96\%, kelas IV 95\%, kelas V 94\%, dan kelas VI 93\%. Persentase internalisasi nilai kejujuran tesebut digambarkan sebagai berikut:

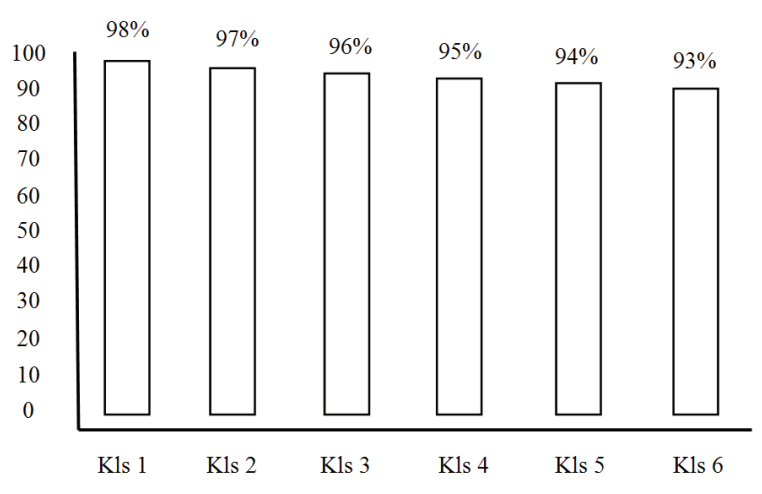

Keterangan:

Kelas I : Persentase nilai kejujuran 98\%

Kelas II : Persentase nilai kejujuran 97\%

Kelas III : Persentase nilai kejujuran 96\%

Kelas VI : Persentase nilai kejujuran 95\%

Kelas $V \quad$ : Persentase nilai kejujuran 94\%

Kelas VI : Persentase nilai kejujuran 93\%

Dalam pelaksanaan tata tertib, tugas guru wajib merasa memberi keteladanan berupa: (1) nilai kedisiplinan; (2) nilai kejujuran; (3) nilai tanggung jawab; (4) nilai toleransi; (5) nilai sportifitas; (6) nilai mengawasi siswa dalam melaksanakan tugas kebersihan; (7) membina siswa tertib membeli jajanan sekolah di kantin kejujuran; dan (8) membuat dan mengisi catatan pribadi siswa sikap jujurnya.

\section{Deksripsi tentang Masalah-Masalah yang Berkaitan dengan Pelaksanaan Pengembangan Pendidikan Antikorupsi Berbasis Kantin Kejujuran di SD Model Tlogowaru Kota Malang}

Proses interaksi nilai-nilai kejujuran pada anak didik, guru, kepala sekolah, dan orang tua, nampaknya sampai saatini masih mengalami masalah dalam praktiknya. Beberapa hal yang menyebabkan timbulnya permasalahan dalam menciptakan suasana jujur dalam kehidupan sekolah yang berbasis kantin kejujuran, adalah adanya beberapa kelas yang kurang melakukan sosialisasi nilai-nilai antikorupsi dan kejujuran yang tercantum dalam visi, misi, dan tujuan pendidikan di sekolah. Di beberapa kelas, komitmen warga kelas dalam mewujudkan nilai-nilai antikorupsi dan nilai kejujuran cenderung rendah, hal ini dikarenakan (1) sekolah masih mengutamakan aspek kognitif; (2) kondisi lingkungan sekolah terutama guru masih mengutamakan nilai ekonomi; (3) kurangnya 
sosialisasi sekolah terhadap pentingnya peningkatan pelaksanaan nilai-nilai kejujuran dan antikorupsi dan kecenderungan warga sekolah yang kurang peduli terhadap penanaman nilai kejujuran dan antikorupsi.

Selain penilaian moral tersebut di atas, masih ditemukan fakta bahwa di sekolah masih ada sikap dan perilaku "kebohongan" siswa, sikap dan perilaku tersebut adalah tidak jujur dalam bertransaksi di kantin kejujuran, tidak jujur dalam mengambil jajanan sekolah sesuai tarifnya, kurang berperan serta menjaga keberhasilan kantin sekolah, mencuri jajanan kantin, mencuri jajanan teman, dan bolos sekolah. Sehubungan dengan tata tertib sekolah yang persentasenya masih rendah (34\%) data dilapangan membuktikan rendahnya persentase sekolah yang memiliki tata tertib untuk kepala sekolah dikarenakan tata tertib untuk seolah hanya diketahui oleh Dinas Pendidikan dan tidak disosialisasikan atau dipajang di sekolah dan tata tertib untuk guru sama. Dengan rendahnya tata tertib sekolah menyebabkan perilaku moral warga sekolah kurang terkontrol. Perilaku tersebut adalah masih adanya warga sekolah yang terlambat masuk seklah, suka berbohong, kurang peduli nasihat guru, membandingkan sikap dan perilaku guru terhadap dirinya, merendahkan karya guru, menghina hasil kerja temannya, tidak mengenakan seragam sekolah, dan membuang sampah sembarangan dilingkungan sekolah.

Selain masalah di atas, masalah-masalah yang di SD adalah masalah kantin sekolah yang kotor dan tidak terawat, coretan-coretan di kantin sekolah, sampah yang berceceran di sembarang tempat, asesoris dan pajangan jajanan kantin yang kurang tertata dan kurang terawat, jajanan kantin yang mengandung zat pewarna bukan makanan, jajanan kantin yang terkesan kurang bersih dan kurang higinis, dan di lingkungan kantin sekolah yang mengandung zat pengawat makanan.

Fakta lain yang ditemukan melalui observasi dan wawancara di beberapa kelas di sekolah dasar adalah penyenlenggaraan pendidikan antikorupsi belum dirancang secara sistematis dengan prinsipprinsip pendidikan antikorupsi dalam pendidikan antikorupsi. Berbagai aturan uang dikenakan pada siswa cenderung bersifat sepihak yakni kewajiban dan tanggun jawab siswa yang ditonjolkan dan terkesan guru dan kepala sekolah sangat mendominasi. Tata tertib siswa ada, tata tertib guru ada, namun kurang tampak bagaimana hubungan antara siswa dengan guru, antara guru dengan kepala sekolah, antara sekolah dengan orang tua kurang tampak.

\section{PEMBAHASAN}

Temuan penelitian menunjukkan bahwa penyelenggaraan pendidikan antikorupsi berbasis kantin kejujuran di sekolah belum di kelola dan dilaksanakan secara sistematis. Hal ini peneliti menduga karena kurangnya pengetahuan dan pemahaman pihak sekolah terhadap pelaksanaan pendidikan antikorupsi yang berbasis kantin kejujuran. Pelaksanaan pendidikan karakter berbasis kantin kejujuran memang dilaksanakan secara terintegrasi, tetapi kurang terprogram dengan baik. Hasil penelitian Samawi (2014) menyimpulkan bahwa sebagian besar guru TK di kota Malang masih mengalami kesulitan dalam pembelajaran kejujuran untuk menumbuhkan karakter antikorupsi pada anak TK. Hal ini sejalan dengan pendapat Depdiknas (2009:9-10), seharusnya penyelenggaraan pendidikan anti korupsi dilaksanakan secara terprogram. Penyelenggaraan pendidikan antikorpusi berbasis kantin kejujuran terkesan kurang dilakukan sesuai dengan landasan teoritik pendidikan antikorupsi. menurut peneliti, pendidikan antikorupsi berbasis kantin kejujuran meskipun dilaksanakan secara terintegrasi, seharusnya penyelenggaraan pendidikan antikorupsi direncanakan dan dilaksanakan secara sistematik. Nilai-nilai kejujuran yang ingin dikembangkan hendaknya secara eksplisit ataupun implisit tampak dalam visi, misi, dan tujuan sekolah.Visi, misi, dan tujuan pendidikan antikorupsi seharusnya juga dipahami oleh seluruh warga sekolah. Sesuai dengan hasil penelitian Badeni (2014:19) bahwa model pembelajaran pembentukan karakter akan efektif bila dilakukan secara terpadu antara model pembelajaran karakter secara efektif, pendekatan penanaman nilai, pendekatan pembangunan rasional moral kognitif, pendekatan anlisis nilai, klarifikasi nilai, pembiasaan, dan reward and challenge. Warga sekolah tidak hanya memahaminya tetapi juga perlu membangun komitmen bersama untuk mencapai visi, misi, dan tujuan pendidikan antikorupsi di sekolah. Hal ini sesuai dengan pendapat Aditjondro (2002) bahwa Negara harus berperan aktif dalam melaksanakan pendidikan anti korupsi sejak usia sekolah dasar. 
Penyelanggaraan pendidikan antikorupsi, seharusnya dibangun berdasarkan teori pendidikan antikorupsi. Tidak sedikit sekolah-sekolah yang cenderung melaksanakan pendidikan antikorupsi, misalnya Pendidikan Agama, Pendidikan Pancasila dan Kewarganegaraan, Pendidikan Akhlak dan Budi Pekerti, namun masih cenderung bersifat kognivistik. Praktek pendidikan antikorupsi di sekolah banyak yang terpeleset menjadi yang overkognivistik, padahal mestinya tidak demikian. Berdasarkan hasil pengembangan model pendidikan antikorupsi (Daulay, 2013:40) adalah implementasi model pendidikan antikorupsi melalui media komik sebagai media pembelajaran menunjukkan peningkatan pemahaman siswa mengenai pengertian korupsi dan mengatasinya. Montessori (2012) mengemukakan bahwa pembelajaran antikorupsi tidak dapat dilaksanakan secara konvesional, melainkan harus didesain sedemekian rupa sehingga aspek kognisi, afeksi, dan korasi siswa mampu dikembangkan secara berkelanjutan. Dalam sebuah teori pembelajaran antikorupsi seperti yang dikemukakan Hadjapamekas (2008) menyebutkan tingginya kasus korupsi disebabkan beberapa hal, diantaranya (a) kurang keteladanan para pemimpin, (b) lemahnya komitmen dan konsistensi penegakan hukum dan peraturan perundangan, (c) rendahnya integrasi dan profesionalisme, dan (d) lemahnya keimanan, kejujuran, rasa malu, moral, dan etika.

Disisi lain, Hakim (2012) mengemukakan ada dua model yang dapat dilakukan oleh sekolah dalam menyeimbangkan kurikulum pendidikan terintegrasi pada pendidikan agama. Pertama, proses pendidikan harus menumbuhkan kepedulian sosial-normatif, membangun penalaran obyektif, dan mengembangkan perspektif universal pada individu. Kedua, pendidikan harus mengarah pada peyemaian strategis, yaitu kualitas pribadi individu yang kosekuen dan kokoh dalam keterlibatan peran sosialnya.

Anak-anak kita di samping perlu dikembangkan pengetahuan dan wawasan tentang "baik - buruk" dan "halal - haram", mana yang boleh dilakukan dan mana yang tidak boleh dilakukan, perasaan dan kesadarannya perlu dipertajam dengan aktifitas pembelajaran yang menyentuh hati, juga perlu dibiasakan melakukan praktik-praktik kehidupan yang bermoral secara nyata dilingkungan sekolah. Persoalan keteladanan juga menjadi masalah yang sangat mendasar dalam praktik pendidikan antukorupsi. Suasana pendidikan antikorupsi akan sangat kondusif jika di tengah kehidupan sekolah, guru-guru, kepala sekolah, para siswa, orang tua, dan berbagai pihak yang terlibat didalamnya "patut diteladani". Banyak contoh pendidikan antikorupsi yang berhasil karena kepala sekolah, guru, dan siswa serta semua pihak menjalankan kepemimpinan moral. Kepemimpinan moral itu, menurut Sergiovani (1992) ditandai dengan adanya "satunya nilai-nilai yang diyakini dengan ucapan dan perbuatan". Satunya nilai, ucapan dan perbuatan yang konsiten, dengan kepemimpinan moral inilah yang akan melahirkan "kharisma". Jika kepala sekolah, guru, dan siswanya memiliki kharisma yang tinggi maka keberhasilan pendidikan antikorupsi diperkirakan berhasil dengan gemilang. Dikuatkan dengan hasil penelitian Akbar (2014:149) bahwa secara khusus model pendidikan karakter yang baik, digambarkan dengan dicanangkan visi satuan pendidikan yang memuat nilai-nilai karakter yang baik yang akan dijangkau eksplisit dalam rumusan visi, tujuan, dan harapan masa depan.

\section{SIMPULAN DAN SARAN}

\section{Simpulan}

Berdasarkan hasil dan pembahasan penelitian dapat diambil kesimpulan sebagai berikut ini. Pertama, SD, telah menerapkan pengembangan pendidikan antikorupsi berbasis kantik kejujuran secaraterintegrasidengan berbagai tema pembelajaran di kelas dan praktik kehidupan di sekolah. Namun, pelaksanaan pengembangan pendidikan antikorupsi tersebut belum dilakukan secara sistemik, sistematik, dan terprogram secara khusus, dan masih belum optimal sesuai prinsip-prinsip pengembangan pendidikan antikorupsi. Hampir diseluruh kelas yang diteliti tidak memiliki Grand Design pengembangan pendidikan antikorupsi secara terprogram. Tata tertib disusun secara sepihak dan kurang disosialisasikan keseluruh kelas dan kurang adanya komitmen untuk mewujudkannya. Basis nilai-nilai kejujuran dan kedisiplinan yang ditawarkan dalam penelitian ini belum sepenuhnya terakomodasi dalam pengembangan pendidikan antikorupsi secara optimal. Kedua, masalah-masalah praktik pengembangan pendidikan antikorupsi yang ditemukan dalam penelitian ini adalah: (a) pengembangan pendidikan antikorupsi belum dibangun secara sitemik dan sistematik sesuai prinsip-prinsip pengembangan pendidikan antikorupsi; (b) nilai-nilai kejujuran 
dan kedisiplinan yang ditawarkan dalam penelitian ini belum seluruhnya terakomodasi dalam berbagai tata tertib yang berlaku di sekolah secara optimal; (c) visi, misi, dan tujuan pengembangan pendidikan antikorupsi kurang tersosialisasikan, komitmen yang rendah dan kurang dilaksanakan seara optimal; (d) berbagai tatanan yang diciptakan untuk menunjang pengembangan pendidikan antikorupsi di sekolah masih didominasi oleh guru dan kepala sekolah dan belum banyak melibatkan siswa dan orang tua siswa dan cenderung menuntut kewajiban dan tanggung jawab serta kurang memperhatikan hak pihak-pihak terkait; (e) berbgai tatanan tersebut kurang ditegakkan secara optimal; (f) masih banyak perilaku siswa dan kepala sekolah yang kurang sesuai dengan nilai kejujuran dan kedisiplinan; dan (g) diberbagai kelas belum begitu banyak yang menerapkan hukuman berdasarkan kesadaran diri dan kesadaran kelompok atas berbagai pelaksanaan tata tertib sekolah.

\section{Saran}

Berdasarkan kesimpulan di atas, maka disarankan sebagai berikut: (1) perlu dikembangkan sebuah model pengembangan pendidikan antikorupsi di sekolah dasar yang sistemik dan sistematik dengan dukungan berbagai tatanan dan perangkat kantin kejujuran; (2) spesifikasi pengembangan pendidikan antikorupsi di sekolah dasar setidak-tidaknya mencakup aspek: (a) Grand Design pengembagan pendidikan antikorupsi; (b) penataan situasi fisik untuk kantin kejujuran; (c) penataan kehidupan sosial di sekolah dasar untuk pengebangan pendidikan antikorupsi di sekolah dasar; (f) penyempurnaan tata tertib bagi siswa, guru, kepala sekolah, orang tua siswa, dan tenaga adiministratif untuk pengembangan pendidikan antikorupsi; (g) program-program kegiatan untuk pengembangan pendidikan antikorupsi; (h) model-model pengembangan pendidikan antikorupsi di sekolah dasar yang tertuang dalam sebuah buku pedoman pengembangan pendidikan antikorupsi di sekolah dasar; (3) pengembangan buku pedoman pendidikan antikorupsi berbasis kantin kejujuran di sekolah dasar perlu dilakukan sebagai tindak lanjut dari produk penelitian.

\section{DAFTAR RUJUKAN}

Aditjondro, G. J. 2002. Bukan Persoalan Telur dan Ayam. Membangun Suatu Kerangka yang Lebih Holistik bagi Gerakan Anti-Korupsi di Indonesia. Yogyakarta: Insist Press.

Adisusilo, S. 2011. Nasionalisme-Demokrasi-Civil Society. Yogyakarta: USD.

Akbar, S. 2010. Model Pembelajaran Nilai dan Karakter Berbasis Nilai Kehidupan di Sekolah Dasar. Jurnal Ilmu Pendidikan. 17(1) : 46-54.

Akbar, S. 2014. Model Pendidikan Karakter Yang Baik (Studi Lintas Situs Bests Practices). Jurnal Sekolah Dasar. 24(2):39-151.

Badeni. 2014. Model Pendidikan Nilai Budi Pekerti Berbasis Kearifan Lokal bagi Siswa SD. Jurnal Sekolah Dasar. 23(1):19-30.

Daulay. 2013. Pengembangan Model Pendidikan Antikorupsi melalui Media Komik bagi Siswa SD. Jurnal Sekolah Dasar. 22(1): 28-41.

Ghofur, S. A. 2009. Merancang Kurikulum Pendidikan Antikorupsi. Jurnal Pendidikan Islam. 1(1):37-46.

Hakim, L. 2012. Model Integrasi Pendidikan Anti Korupsi dalam Kurikulum Pendidikan Islam. Jurnal Pendidikan Agama Islam-Ta'lim. 10(2):141-156.

Hadjapamekas, R.E. 2008. Circulaire Du Conseil D'Administration De L'itie. French: EITI.

Kemendikbud. 2011. Pendidikan Anti Korupsi untuk Perguruan Tinggi. Jakarta: Kemendikbud RI.

Montessori, M. 2012. Pendidikan Antikorupsi sebagai Pendidikan Karakter di Sekolah. Jurnal Demokrasi. 11(2):293-300.

Samawi, A. 2014. Pembelajaran Karakter Kejujuran di Taman Kanak-kanak. Jurnal Ilmu Pendidikan. 41:16-122.

Sergiovanni. 1992. Why We Should Seek Subtitutes for Leadership. Educational Leardership. 5:41-45. 